\title{
Phosphites for the control of anthracnose in common bean
}

\author{
Stélio Jorge Castro Gadaga(1), Mário Sobral de Abreu(1), \\ Mário Lúcio Vilela de Resende ${ }^{(1)}$ and Pedro Martins Ribeiro Júnior(2)
}

\begin{abstract}
(1)Universidade Federal de Lavras, Departamento de Fitopatologia, Caixa Postal 3037, CEP 37200-000 Lavras, MG, Brazil. E-mail: steliogadaga@gmail.com, msabreu@ufla.br, mlucio@ufla.br (2)Embrapa Semiárido, Rodovia BR-428, Km 152, Zona Rural, Caixa Postal 23, CEP 56302-970 Petrolina, PE, Brazil. E-mail: pedro.ribeiro@embrapa.br
\end{abstract}

\begin{abstract}
The objective of this work was to evaluate the effect of phosphites in the protection of common bean (Phaseolus vulgaris) against anthracnose. Different phosphite formulations were evaluated by quantifying peroxidase and polyphenol oxidase activity, total phenols, and lignin content. The treatments consisted of sprayings, in the V4, R5, and R7 stages, with: the $\mathrm{K}, \mathrm{Zn}, \mathrm{Mn}, \mathrm{K}+\mathrm{Mn}, \mathrm{K}+$ salicyclic acid, and $\mathrm{Cu}$ phosphites; salicylic acid; acibenzolar-S-methyl; the fungicide azoxystrobin; besides a control, without sprayings. The area under the disease progress curve was lower in plants that received applications of the $\mathrm{K}$ and $\mathrm{Mn}$ phosphites, whose values ranged between 74 and $81 \%$, compared with the control. The $\mathrm{K}, \mathrm{Zn}$, and $\mathrm{K}+$ salicyilic acid phosphites were effective in controlling the disease. In addition, disease severity was lower with the application of the $\mathrm{K}, \mathrm{Zn}$, and Mn phosphites than with the control. Enzyme (peroxidases and polyphenol oxidases) activity and levels of soluble phenols were higher in common bean plants treated with the $\mathrm{K}$ and Mn phosphites, although no change was detected in the levels of soluble lignin in the same tissue. Phosphite application reduces the severity of the disease, can enhance enzymatic activity, and is an effective alternative for the control of anthracnose in common bean.
\end{abstract}

Index terms: Colletotrichum limdemuthianum, Phaseolus vulgaris, alternative control, enzymatic activity, phenolic compounds.

\section{Fosfitos para o controle da antracnose em feijoeiro comum}

Resumo - O objetivo deste trabalho foi avaliar o efeito de fosfitos na proteção do feijoeiro comum (Phaseolus vulgaris) contra antracnose. Diferentes formulações de fosfitos foram avaliadas por meio da quantificação da atividade de peroxidases e polifenoloxidases, de fenóis totais e do teor de lignina. Os tratamentos consistiram de pulverizações, nos estádios V4, R5 e R7, com: fosfitos de K, Zn, Mn, K+Mn, K+ácido salicílico e Cu; ácido salicílico; acibenzolar-S-metil; o fungicida azoxistrobina; além de um controle, sem aplicações. A área abaixo da curva de progresso da doença foi menor em plantas que receberam aplicações dos fosfitos de $\mathrm{K}$ e Mn, cujos valores variaram entre 74 e $81 \%$, em comparação ao controle. Os fosfitos de K, Zn e K+ácido salicílico foram eficazes no controle da doença. Além disso, severidade da doença foi menor com a aplicação dos fosfitos de $\mathrm{K}, \mathrm{Zn}$ e Mn quando comparado ao controle. A atividade de enzimas (peroxidases e polifenoloxidases) e os níveis de fenóis solúveis foram mais elevados em plantas de feijão comum tratadas com os fosfitos de $\mathrm{K}$ e Mn, embora não tenha sido detectada mudança nos níveis de lignina solúvel no mesmo tecido. A aplicação de fosfitos reduz a severidade da doença, pode potencializar a atividade enzimática e é uma alternativa eficaz para o controle da antracnose no feijoeiro comum.

Termos para indexação: Colletotrichum limdemuthianum, Phaseolus vulgaris, controle alternativo, atividade enzimática, compostos fenólicos.

\section{Introduction}

Anthracnose, caused by Colletotrichum lindemuthianum (Sacc. \& Magn.) Scrib, is one of the major diseases of common bean (Phaseolus vulgaris L.) around the world and in Brazil, which is one of the largest bean producers (Carbonell et al., 2010; Chiorato et al., 2010). The disease affects bean plants at all growth stages, causing lesions on leaves, stems, branches, pods, and seeds, which may cause losses of up to $100 \%$ in production when susceptible varieties are used and the conditions are favorable for the pathogen (Rava \& Sartorato, 1994).

Among the main methods for controlling this disease are chemical control and the use of resistant cultivars. However, chemical control with fungicides may cause soil, environmental, and human contamination, whereas plant resistance in cultivars may be broken down by different pathogens. These concerns have fostered the development of eco-friendly technologies

Pesq. agropec. bras., Brasília, v.52, n.1, p.36-44, jan. 2017

DOI: 10.1590/S0100-204X2017000100005 
for plant protection, such as compounds that can induce plant resistance, exploring the endogenous mechanisms of plant defense.

An alternative method for controlling diseases caused by fungi is the use of essential oils, which increases the resistance levels of the treated crop (Garcia et al., 2012). In this case, the induction of resistance involves the activation of latent defense mechanisms in the plants in response to treatments with biotic (extracts, compounds, and molecules extracted from living organisms such as plants and microorganisms) or abiotic (acibenzolar-S-methyl and analogs) agents (Bonaldo et al., 2005).

Also useful in managing plant diseases are the phosphites, originating from the neutralization of phosphorous acid $\left(\mathrm{H}_{3} \mathrm{PO}_{3}\right)$ with a base, which may be sodium hydroxide, potassium hydroxide, or ammonium hydroxide, among others. Potassium hydroxide is the most commonly used to form potassium phosphite, which that can act directly on fungi or activate the defense mechanism of plants (Reuveni, 1997). Tavares et al. (2009) observed that potassium phosphite induced resistance in papaya (Carica papaya L.) plants against Phytophthora palmivora. When applied before and after the inoculation of Phakopsora euvitis, phosphites were reported to reduce the colonization by the pathogen on vine (Vitis labrusca L.) leaves, reducing the disease in about 50\% (Buffara et al., 2013). Guest \& Grant (1991) pointed out that potassium phosphite inhibits the growth of fungal hyphae, acting directly as a toxin on the pathogen, and may also be effective in controlling various other pathogens. Phosphites may also indirectly control pathogens by stimulating the formation of phytoalexin, a natural self-defense substance of the plant (Dercks \& Creasy, 1989).

When plants have developed specific receptor proteins (R-proteins), they can recognize the effector proteins produced by the pathogen, directly or indirectly leading to effector triggered immunity (Dalio et al., 2014).

The objective of this work was to evaluate the effect of phosphites in the protection of common bean (Phaseolus vulgaris) against anthracnose.

\section{Materials and Methods}

Greenhouse and field experiments were conducted from July to October 2009 in the experimental areas of
Universidade Federal de Lavras, in the municipality of Lavras, in the state of Minas Gerais, Brazil $\left(21^{\circ} 13^{\prime} 35^{\prime \prime} \mathrm{S}\right.$, $44^{\circ} 58^{\prime} 31^{\prime \prime} \mathrm{W}$ and $\left.21^{\circ} 12^{\prime \prime} 18^{\prime \prime} \mathrm{S}, 44^{\circ} 58^{\prime} 43^{\prime \prime} \mathrm{W}\right)$.

The greenhouse experiment was carried out in a randomized complete block design with three replicates. The experimental plot consisted of six plants, with two pots containing three plants each. Five common bean seeds from the carioca group, cultivar BRS Majestoso, were grown in the pots, which contained $3 \mathrm{~L}$ of substrate with soil: sand: manure (2:1:1), and were fertilized with $5 \mathrm{~g}$ N-P-K (4-14-8), under greenhouse conditions with an average temperature of $25 \pm 3^{\circ} \mathrm{C}$ and relative humidity of $70 \% \pm 5^{\circ} \mathrm{C}$. Thinning was performed 15 days after emergence, leaving the three more vigorous and homogeneous seedlings.

The experiment in the field was also carried out in a randomized complete block design with three replicates, and the experimental plot consisted of five $3-\mathrm{m}$ rows containing 30 plants each, spaced at $0.5 \mathrm{~m}$. The three internal rows that formed the useful plot were selected and marked, and nine plants were evaluated; the two outer rows formed the boundary of the experiment.

Data from both experiments were subjected to the analysis of variance using the Sisvar software, version 5.1, Build 72 (Universidade Federal de Lavras, Lavras, MG, Brazil), and mean separation was performed by Tukey's test when the F-test was significant at 5\% probability.

In the experiment under greenhouse conditions, a pure colony of $C$. lindemuthianum race $65 \mathrm{LV} 81$ in M3 medium, from the collection of the laboratory of plant resistance of the Biology Department of Universidade Federal de Lavras, was multiplied in test tubes containing young autoclaved pods (twice for 1 hour at $120^{\circ} \mathrm{C}$ ) of common bean plants; the test tubes containing agar-water were maintained in a growth chamber at $22 \pm 1^{\circ} \mathrm{C}$ for ten days. Inoculation of the pathogen was performed on the third day in the pods using a 3-mm mycelial disc. After sporulation, to obtain a conidial suspension, $15 \mathrm{~mL}$ of distilled water were added to the test tubes and stirred, and the obtained suspension was filtered through a double cheesecloth. Conidia were quantified with the aid of a Neubauer counting chamber and adjusted to a concentration of $1 \times 10^{6}$ conidia $\mathrm{mL}^{-1}$ for inoculation in common bean seedlings. Disease severity was assessed five times, from July 2 to 30, 2009, at seven-day intervals, after 
inoculation in the greenhouse experiment, using the diagrammatic scale developed by Godoy et al. (1997). The six plants that made up the experimental plot were evaluated at 7, 14, 21, 28, and 35 days after inoculation, in order to calculate the area under the disease progress curve (AUDPC) (Shaner \& Finney, 1977).

To control anthracnose in the greenhouse, phosphites were applied to leaves to the point of runoff, using manual sprayers model 78605/050 (Tramontina, Carlos Barbosa, RS, Brazil), at the third trifoliate (V4), preflowering (R5), and pod formation (R7) stages. The treatments applied were: $5 \mathrm{~mL} \mathrm{~L}^{-1}$ potassium phosphite 1 (K1), containing $340 \mathrm{~g} \mathrm{~L}^{-1} \mathrm{P}_{2} \mathrm{O}_{5}$ and $240 \mathrm{~g} \mathrm{~L}^{-1} \mathrm{~K}_{2} \mathrm{O}$ Reforce (Agrichem do Brasil Ltda., Ribeirão Preto, SP, Brazil); $5 \mathrm{~mL} \mathrm{~L}^{-1} \mathrm{Zn}$ phosphite, with $340 \mathrm{~g} \mathrm{~L}^{-1} \mathrm{P}_{2} \mathrm{O}_{5}$ and $100 \mathrm{~g} \mathrm{~L}^{-1} \mathrm{Zn}$, Reforce Zn (Agrichem do Brasil Ltda., Ribeirão Preto, SP, Brazil); $5 \mathrm{~mL} \mathrm{~L}^{-1} \mathrm{Mn}$ phosphite, with $510 \mathrm{~g} \mathrm{~L}^{-1} \mathrm{P}_{2} \mathrm{O}_{5}$ and $97 \mathrm{~g} \mathrm{~L}^{-1} \mathrm{Mn}$, Reforce $\mathrm{Mn}$ (Agrichem do Brasil Ltda., Ribeirão Preto, SP, Brazil); $5 \mathrm{~mL} \mathrm{~L}^{-1} \mathrm{Mn}+\mathrm{K} 1$ phosphite, with $510 \mathrm{~g} \mathrm{~L}^{-1} \mathrm{P}_{2} \mathrm{O}_{5}, 97 \mathrm{~g} \mathrm{~L}^{-1}$ $\mathrm{Mn}$, and $240 \mathrm{~g} \mathrm{~L}^{-1} \mathrm{~K}_{2} \mathrm{O}$, Reforce $\mathrm{Mn}+\mathrm{K} 1$ (Agrichem do Brasil Ltda., Ribeirão Preto, SP, Brazil); $5 \mathrm{~mL} \mathrm{~L}^{-1}$ $\mathrm{K} 1+$ salicylic acid (SA) phosphite, with $34 \mathrm{~g} \mathrm{~L}^{-1} \mathrm{P}_{2} \mathrm{O}_{5}$, $24 \mathrm{~g} \mathrm{~L}^{-1} \mathrm{~K}_{2} \mathrm{O}$, and 5\% SA, Reforce+SA (Agrichem do Brasil Ltda., Ribeirão Preto, SP, Brazil); 1-5 mL L-1 potassium phosphite $2(\mathrm{~K} 2)$, with $434.28 \mathrm{~g} \mathrm{~L}^{-1} \mathrm{P}_{2} \mathrm{O}_{5}$ and $403.26 \mathrm{~g} \mathrm{~L}^{-1} \mathrm{~K}_{2} \mathrm{O}$, Nutri Phite (Iharabras S.A., Cajuru de Sorocaba, SP, Brazil); $5 \mathrm{~mL} \mathrm{~L}^{-1}$ potassium phosphite 3 (K3), with $420 \mathrm{~g} \mathrm{~L}^{-1} \mathrm{P}_{2} \mathrm{O}_{5}$ and $280 \mathrm{~g} \mathrm{~L}^{-1} \mathrm{~K}_{2} \mathrm{O}$, Pepfós (Pepita Fertilizantes Ltda., Poços de Caldas, MG, Brazil); $5 \mathrm{~mL} \mathrm{~L}^{-1} \mathrm{Cu}$ phosphite, with $268 \mathrm{~g} \mathrm{~L}^{-1} \mathrm{P}_{2} \mathrm{O}_{5}$ and $53.6 \mathrm{~g} \mathrm{~L}^{-1} \mathrm{Cu}$, Fulland (Sudoeste Fertilizantes Ltda., Araxá, MG, Brazil); $0.25 \mathrm{~g} \mathrm{~L}^{-1}$ a.i. SA (Merck Brazil, Jacarepaguá, RJ, Brazil); $0.0625 \mathrm{~g} \mathrm{~L}^{-1}$ a.i. acibenzolarS-methyl (ASM) (Syngenta Proteção de Cultivos Ltda., Santo Amaro, SP, Brazil); $3 \mathrm{~mL} \mathrm{~L}^{-1}$ Agro-Mos, with $35 \mathrm{~g} \mathrm{~L}^{-1} \mathrm{Cu}, 27.5 \mathrm{~g} \mathrm{~L}^{-1} \mathrm{~S}$, and $25 \mathrm{~g} \mathrm{~L}^{-1} \mathrm{Zn}$, Alltech (Crop Science Brasil, Araucária, PR, Brazil); $0.3 \mathrm{~g} \mathrm{~L}^{-1}$ of the fungicide azoxystrobin (Syngenta Proteção de Cultivos Ltda., Santo Amaro, SP, Brazil); and a control, without sprayings. Inoculation was carried out at 45 days after sowing in the R6 stage by spraying the inoculum suspension to the point of runoff. After inoculation, the pots with plants were covered with transparent plastic bags during 14 hours to provide a moist chamber, in order to promote penetration and colonization of the fungus. Disease severity was evaluated five times after the treatments, from July 2 to 30,2009 , at seven-day intervals.

For the management of anthracnose in the field, phosphites, SA, ASM, and azoxystrobin were also applied on the leaves three times, using a $20-\mathrm{L}$ capacity portable sprayer, at the V4, R5, and R7 stages. The treatments were: $5 \mathrm{~mL} \mathrm{~L}^{-1} \mathrm{~K} 1$ phosphite, with $340 \mathrm{~g} \mathrm{~L}^{-1} \mathrm{P}_{2} \mathrm{O}_{5}$ and $240 \mathrm{~g} \mathrm{~L}^{-1} \mathrm{~K}_{2} \mathrm{O}$, Reforce (Agrichem do Brasil Ltda., Ribeirão Preto, SP, Brazil); $5 \mathrm{~mL} \mathrm{~L}^{-1}$ Zn phosphite, with $340 \mathrm{~g} \mathrm{~L}^{-1} \mathrm{P}_{2} \mathrm{O}_{5}$ and $100 \mathrm{~g} \mathrm{~L}^{-1} \mathrm{Zn}$, Reforce Zn (Agrichem do Brasil Ltda., Ribeirão Preto, SP, Brazil); $5 \mathrm{~mL} \mathrm{~L}^{-1} \mathrm{Mn}$ phosphite, with $510 \mathrm{~g} \mathrm{~L}^{-1}$ $\mathrm{P}_{2} \mathrm{O}_{5}$ and $97 \mathrm{~g} \mathrm{~L}^{-1} \mathrm{Mn}$, Reforce $\mathrm{Mn}$ (Agrichem do Brasil Ltda., Ribeirão Preto, SP, Brazil); $5 \mathrm{~mL} \mathrm{~L}^{-1}$ $\mathrm{K} 1+\mathrm{SA}$ phosphite, with $34 \mathrm{~g} \mathrm{~L}^{-1} \mathrm{P}_{2} \mathrm{O}_{5}, 24 \mathrm{~g} \mathrm{~L}^{-1} \mathrm{~K}_{2} \mathrm{O}$, and 5\% SA, Reforce+SA (Agrichem do Brasil Ltda., Ribeirão Preto, SP, Brazil); $0.25 \mathrm{~g} \mathrm{~L}^{-1}$ a.i. SA (Merck Brazil, Jacarepaguá, RJ, Brazil); $0.0625 \mathrm{~g} \mathrm{~L}^{-1}$ a.i. ASM (Syngenta Proteção de Cultivos Ltda., Santo Amaro, SP, Brazil); $0.3 \mathrm{~g} \mathrm{~L}^{-1}$ of the fungicide azoxystrobin (Syngenta Proteção de Cultivos Ltda., Santo Amaro, SP, Brazil); and a control, without sprayings. Inoculation was not carried out in the field since this happened naturally; the presence of the pathogen was confirmed in the previous crop planted with common bean, forming the initial source of the inoculum. The severity of the disease was also evaluated seven times after the application, from July 2 to 30, 2009, at sevenday intervals.

Following the experiments in the greenhouse and in the field, the biochemical mechanisms of common bean plants were characterized, in order to understand more about the protective responses against $C$. lindemuthianum with phosphite application. For this, the plants were treated with the two products that performed better in controlling anthracnose in both experiments: $5 \mathrm{~mL} \mathrm{~L}^{-1} \mathrm{~K} 1$ phosphite, Reforce (Agrichem do Brasil Ltda., Ribeirão Preto, SP, Brazil), also used as a standard product; and $5 \mathrm{~mL} \mathrm{~L}^{-1} \mathrm{Mn}$ phosphite, Reforce Mn (Agrichem do Brasil Ltda., Ribeirão Preto, SP, Brazil). These products were selected to compare the defense responses of 'BRS Majestoso' common bean plants, based on peroxidase and polyphenol oxidase activity, and on the contents of total soluble phenolics and lignin. The products were applied 25 days after planting at the $\mathrm{R} 4$ vegetative growth stage. Seven days after the products were applied, inoculation was performed by spraying the 
inoculum to the point of runoff using manual sprayers, model 78605/050 (Tramontina, Carlos Barbosa, RS, Brazil) with a capacity of $500 \mathrm{~mL}$. After inoculation, the plants in the pots were covered with transparent plastic bags during 14 hours, to provide a moist chamber, in order to promote fungal penetration and colonization. To determine the activity of peroxidases and polyphenol oxidases, as well as the contents of total soluble phenols, tissues were collected from the oldest to the youngest leafs at $0,0.5,1,3,6,7.5,8,10,13$, and 17 days after spraying with the inductor products. To obtain the lignin content, leaf tissues were collected at 10,13 , and 17 days after spraying.

The samples used to determine enzyme activities were packed in properly-identified aluminum foil, frozen in liquid nitrogen, and stored at $-80^{\circ} \mathrm{C}$ in a freezer. To prepare the extracts, each frozen sample was weighed and macerated individually with the aid of a pestle in a porcelain mortar cooled on ice, and homogenized in $50 \mathrm{mmol} \mathrm{L}^{-1}$ sodium acetate buffer, $\mathrm{pH} 5.2$, at a ratio of $1 \mathrm{~g}$ fresh sample material to $8 \mathrm{~mL}$ buffer. The homogenized extract was centrifuged in a 5804 R centrifuge (Eppendorf do Brasil, São Paulo, SP, Brazil) at 24,148.8 $g$ for $10 \mathrm{~min}$, and the supernatant was collected in plastic microtubes, stored at $-80^{\circ} \mathrm{C}$ for posterior analysis.

Total protein concentration was obtained by the Bradford method (1976), adjusting a standard curve previously determined with the use of solutions with known concentrations of bovine serum albumin $\left(0-100 \mu \mathrm{g} \mathrm{mL}^{-1}\right)$, correlating the protein concentration with absorbance readings in an 83057-30 spectrophotometer (BioTek U.S., Winooski, VT, USA), at $595 \mathrm{~nm}$.

Peroxidase (EC 1.11.1.6 catalase) activity was determined using the methodology described by Urbanek et al. (1991). Guaiacol was used as the electron donor and hydrogen peroxide as the receiver. The reaction, catalyzed by the peroxidases, produces a colored 3,3-dimethoxy-4,4-biphenylquinone compound. An aliquot of $30 \mu \mathrm{L}$ crude extract was added to $170 \mu \mathrm{L}$ of a solution containing $0.02 \mathrm{~mol} \mathrm{~L}^{-1}$ guaiacol, $0.06 \mathrm{~mol} \mathrm{~L}^{-1}$ hydrogen peroxide, and $50 \mathrm{mmol} \mathrm{L}^{-1}$ sodium acetate buffer $\mathrm{pH}$ 5.2. The mixture was incubated at $30^{\circ} \mathrm{C}$ for $10 \mathrm{~min}$ and its absorbance was measured at $480 \mathrm{~nm}$. The variation of 1.0 unit of absorbance per minute was assumed to be 1.0 unit of peroxidase activity per milligram of protein per minute
[ $\Delta 480 \mathrm{~nm}$ (mg protein per minute)]. The enzymatic activity was performed in triplicate.

The polyphenol oxidase (EC 1.14.81.1 purified polyphenol oxidase) activity was determined by adding $50 \mu \mathrm{L}$ of the enzyme extract to $150 \mu \mathrm{L}$ of a solution containing potassium phosphate buffer $\mathrm{pH}$ 6.5 and $20 \mathrm{mmol} \mathrm{L}^{-1}$ catechol (Gauillard et al., 1993). After incubation at $30^{\circ} \mathrm{C}$, for $10 \mathrm{~min}$, the increase in absorbance was measured at $410 \mathrm{~nm}[\Delta 410 \mathrm{~nm}(\mathrm{mg}$ protein per minute)]. Analyses were also performed in triplicate.

For the determination of lignin content and total soluble phenols, the plant leaf tissues were ground in liquid nitrogen using a mortar and a pestle until obtaining a fine powder. Subsequently, the samples were lyophilized in a free dryer, FreeZone Liter Benchtop (Labconco, Kansas City, MO, USA) for 12 hours. An aliquot of $30 \mathrm{mg}$ of the lyophilized material was transferred to a 2-mL microtube, homogenized with $1.5 \mathrm{~mL}$ of $80 \%$ methanol, and was stirred for 15 hours on a rotary shaker protected from light, at room temperature. The suspension was centrifuged in a $5804 \mathrm{R}$ centrifuge (Eppendorf do Brasil, São Paulo, SP, Brazil) at 24,148.8 $g$ for 5 min. The supernatant (methanol extract) was transferred to a new microtube, which was conducted to obtain total soluble phenols, whereas the solid residue was used to determine lignin. For this, $1.5 \mathrm{~mL}$ of water was added to the solid residue, which was homogenized and centrifuged at $24,148.8 \mathrm{~g}$ for $5 \mathrm{~min}$, at $4^{\circ} \mathrm{C}$, in the same centrifuge. The supernatant was discarded and the residue was dried at $65^{\circ} \mathrm{C}$ for 15 hours. Subsequently, $1.5 \mathrm{~mL}$ mercaptoacetic acid: $2 \mathrm{~mol} \mathrm{~L}^{-1} \mathrm{HCl}(1: 10)$ were added. Then, the microtubes were gently stirred to hydrate the residue and were placed in a boiling water bath, model 102R (Fanem, São Paulo, SP, Brazil) for 4 hours. Afterwards, the microtubes were centrifuged at $24,148.8 \mathrm{~g}$ for $10 \mathrm{~min}$, at $4^{\circ} \mathrm{C}$; the supernatant was discarded; and the precipitate was washed with 1.5 $\mathrm{mL}$ of ultrapure water and centrifuged again, also at $24,148.8 \mathrm{~g}$ for $10 \mathrm{~min}$, at $4^{\circ} \mathrm{C}$. Following this procedure, the supernatant was discarded and the precipitate was resuspended in $1.5 \mathrm{~mL}$ of $0.5 \mathrm{~mol} \mathrm{~L}^{-1} \mathrm{NaOH}$, being kept on a Stickmax rotary shaker (IKA Brasil, Campinas, SP, Brazil) for 15 hours, at room temperature. The mixture was centrifuged at $24,148.8 \mathrm{~g}$ for $10 \mathrm{~min}$, at $4^{\circ} \mathrm{C}$, and the supernatant was transferred to a new microtube, to which $200 \mathrm{~mol} \mathrm{~L}^{-1}$ concentrated $\mathrm{HCl}$ 
were added. The obtained suspension was kept in a cold room, at $4^{\circ} \mathrm{C}$, for 4 hours, in order to allow the precipitation of lignin linked to thioglycolic acid. Then, the mixture was centrifuged at $24,148.8 \mathrm{~g}$ for $10 \mathrm{~min}$, at $4^{\circ} \mathrm{C}$; the supernatant was discarded; and the precipitate was resuspended in $2 \mathrm{~mL}$ of $0.5 \mathrm{~mol} \mathrm{~L}^{-1}$ $\mathrm{NaOH}$. The absorbance values of this solution were determined in a 83057-30 spectrophotometer (BioTek U.S., Winooski, VT, USA), at $280 \mathrm{~nm}$, being calculated based on the lignin curve and expressed in $\mu \mathrm{g}$ of lignin per milligram of dry weight according to Doster \& Bostock (1988), with modifications. For the determination of total soluble phenols, $150 \mu \mathrm{L}$ aliquots of the methanol extract were mixed with $150 \mu \mathrm{L}$ of the $0.25 \mathrm{~N}$ Folin-Ciocalteu reagent, for $5 \mathrm{~min}$, homogenized with $150 \mu \mathrm{L}$ of $1 \mathrm{~mol} \mathrm{~L}^{-1} \mathrm{Na}_{2} \mathrm{CO}_{3}$ for $10 \mathrm{~min}$, and diluted with $1 \mathrm{~mL}$ of ultrapure water, at room temperature, for 1 hour. The absorbance values of this reaction were also determined in a 83057-30 spectrophotometer (BioTek U.S., Winooski, VT, USA), at $725 \mathrm{~nm}$, being calculated based on the catechol curve. The phenolic compounds were expressed in equivalent $\mu \mathrm{L}$ of catechol per milligram of dry weight (Spanos \& Wrolstad, 1990).

The results were evaluated by the analysis of variance, and means were compared by Tukey's test, at 5\% probability, using the Sisvar software, version 5.1 (Build 72) (Universidade Federal de Lavras, Lavras, MG, Brazil).

\section{Results and Discussion}

The evaluation of the disease progress curve (AUDPC) showed that the K1, K2, Mn, and K3 phosphites caused the greatest reductions of anthracnose, of $81,80,77$, and $74 \%$, respectively, being statistically similar to the other treatments but different from the control in the greenhouse experiment (Figure 1). Moreover, K1 phosphite+SA, fungicide, $\mathrm{Zn}$ phosphite, $\mathrm{Cu}$ phosphite, ASM, K+Mn phosphite, Agro-Mos, and SA were statistically identical to each other, although intermediate when compared with the best treatments and the control.

Negri et al. (2011) reported a positive effect of K phosphite in reducing the infection by Monilinia fruticola in $49-73 \%$ in flowers and in $57-84 \%$ in fruits of peach [Prunus persica (L.) Batsch]. Araújo et al. (2010) observed, in vitro and in vivo, that phosphites interfered in the development of Colletotrichum gloeosporioides, causing a decrease of $94 \%$ in the mycelial growth of the colonies and reducing in $62 \%$ the severity of leaf spot caused by Glomerella cingulata when applied 48 hours after inoculation. Fuzitani et al. (2013) also found positive effects of K phosphites in controlling Phytophthora palmivora in Bactris gasipaes Kunth var. gasipaes Henderson. These results show that there is scientific evidence of the beneficial effects of phosphites in controlling plant diseases in several pathosystems.

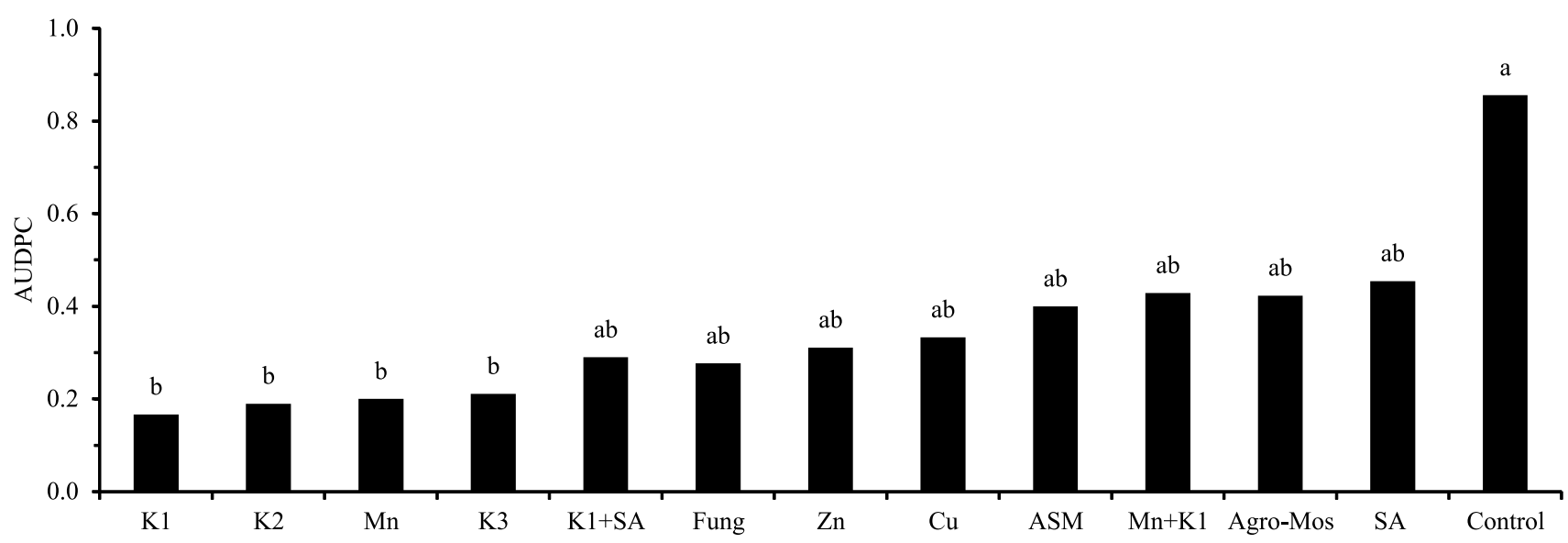

Figure 1. Effect of phosphites, fungicide (Fung), acibenzolar-S-methyl (ASM), Agro-Mos, and salicylic acid (SA) on the area under the disease progress curve (AUDPC) of anthracnose in 'BRS Majestoso' common bean (Phaseolus vulgaris). $\mathrm{K} 1$, potassium phosphite 1; K2, potassium phosphite 2; Mn, manganese phosphite; K3, potassium phosphite 3; Zn, zinc phosphite; and $\mathrm{Cu}$, copper phosphite. Means followed by equal letters do not differ by Tukey's test, at 5\% probability. 
All treatments in the field experiment were statistically similar and reduced the AUDPC in 74 to $90 \%$, in comparison with the control treatment (Figure 2). The best results were with K phosphite, Zn phosphite, Mn phosphite, and ASM, which allowed controlling the disease similarly to the recommended fungicide. Silva et al. (2014) reported that the K and $\mathrm{Ca}$ phosphites reduced the AUDPC in pepper (Capsicum annuum L.) against Pectobacterium carotovorum subsp. carotovorum (Pcc). In the present study, the phosphites were effective in controlling anthracnose in common bean in the field trial. Similar results have also been verified by other authors such as Lins et al. (2011), who observed a decrease in AUDPC when phosphite was applied in mangoes (Mangifera indica L.) to control Lasiodiplodia theobromae. Silva et al. (2013), while evaluating soybean (Glycine $\max$ L.), found that $\mathrm{K}$ phosphite and Mn significantly reduced the AUDPC of mildew and had no effect on powdery mildew and Asian soybean rust.

The activities of peroxidases in common bean plants increased in the treatments with phosphites from the third day after spraying the product, compared with the control (Figure 3 A). A slight decrease was observed in the peroxidase levels of plants treated with $\mathrm{K}$ phosphite, as well as in the control inoculated 7.5 days

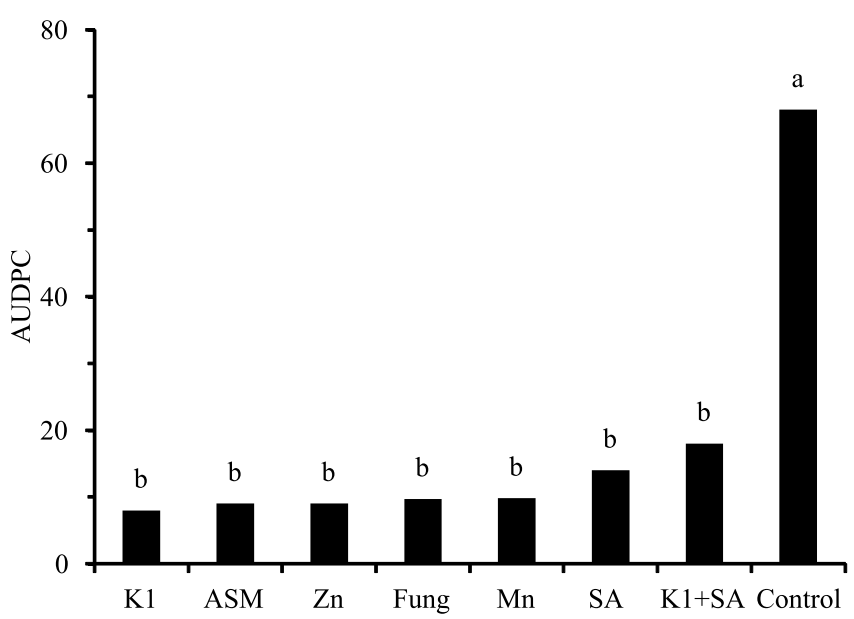

Figure 2. Effect of phosphites, acibenzolar-S-methyl (ASM), fungicide (Fung), and salicylic acid (SA) on the area under the disease progress curve (AUDPC) of anthracnose in 'BRS Majestoso' common bean (Phaseolus vulgaris). $\mathrm{K} 1$, potassium phosphite 1; Zn, zinc phosphite; and Mn, manganese phosphite. Means followed by equal letters do not differ by Tukey's test, at $5 \%$ probability.
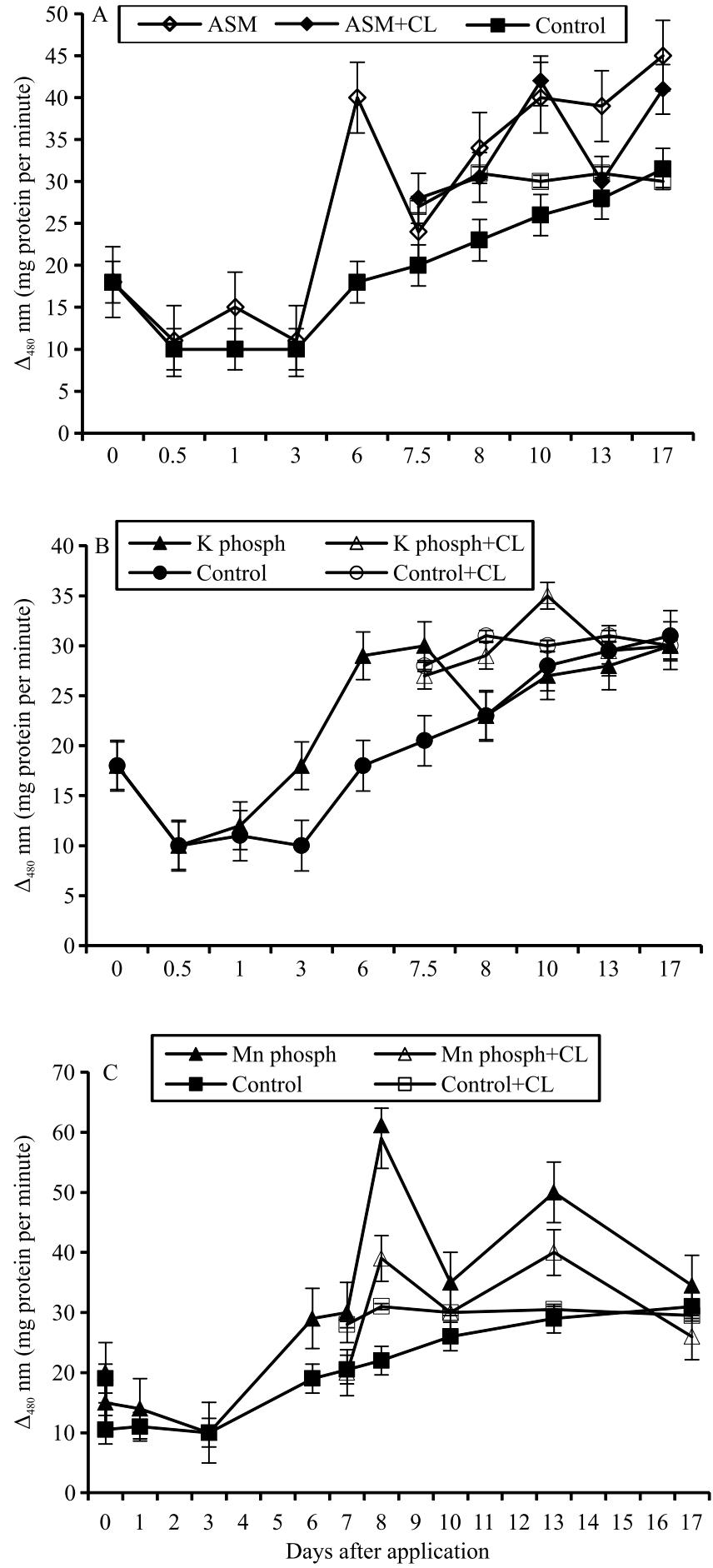

Figure 3. Activity of guaiacol peroxidase in 'BRS Majestoso' common bean (Phaseolus vulgaris) leaves after treatment with: A, acibenzolar-S-methyl (ASM); B, potassium phosphite (K phosph); and $\mathrm{C}$, manganese phosphite ( $\mathrm{Mn}$ phosph), compared with the control. The inoculation with Colletotrichum lindemuthianum (CL) occurred seven days after treatment. Bars indicate standard deviation. 
after the treatment; however, in the uninoculated control, these levels were always higher (Figure 3 B). The plants treated with Mn phosphite showed the greatest differences in the levels of peroxidase over the experimental period (Figure $3 \mathrm{C}$ ). A clear increase was verified in plants treated with $\mathrm{Mn}$ phosphite inoculated or not from the sixth day after treatment, reaching a peak at 8 days and continuing until day 17 (Figure $3 \mathrm{C}$ ).

The polyphenol oxidase activity was similar when the plants were treated with ASM (Figure 4 A), but varied in function of the treatments $\mathrm{K}$ and $\mathrm{Mn}$ phosphites (Figure $4 \mathrm{~B}$ and C). Uninoculated plants treated with $\mathrm{K}$ phosphite showed peak activity of polyphenol oxidase at six days after treatment, performing well above the uninoculated control. However, when inoculation occurred, there was a decrease in these levels with phosphite application and in the control (Figure 4 B). The polyphenol oxidase levels of plants treated with Mn phosphite did not change until the sixth day after treatment; however, after 7.5 days there was a increase in the uninoculated plants treated with Mn phosphite (Figure $4 \mathrm{C}$ ).

The content of total phenolic compounds varied only at ten days after spraying, in the treatments applied with K phosphite, Mn phosphite, and ASM, in comparison with the control; however, in the other two samplings no differences were found between treatments (Table 1). As for lignin, no difference was observed in any of the treatments (Table 2).

The obtained results show that phosphites increase peroxidase activity, as reported by Ribeiro Júnior et al. (2006), who studied phosphite application in inducing the resistance of the cocoa (Theobroma cacao L.) pathosystem to Verticillium dahliae. The authors found a small increase in the peroxidase activity at 13 days after the application of $\mathrm{K}$ phosphite $\left(1.25 \mathrm{~mL} \mathrm{~L}^{-1}\right)$. Several functions are attributed to peroxidases in cellular defense, specifically their involvement in cell wall lignification, suberization, and metabolism, being classified as pathogenesis-related proteins (Loon \& Strien, 1999). Borsato et al. (2010) observed an increase of $65 \%$ in the peroxidase activity 48 hours after inoculation of Uromyces appendiculatus on the susceptible cultivar IPR Juriti of common bean, when compared with the resistant cultivar BR IPA 11 (Brígida). Felipini \& Di Piero (2013) verified that ASM induced resistance by promoting the accumulation of peroxidases and $\beta-1,3$ glucanases in beet (Beta vulgaris
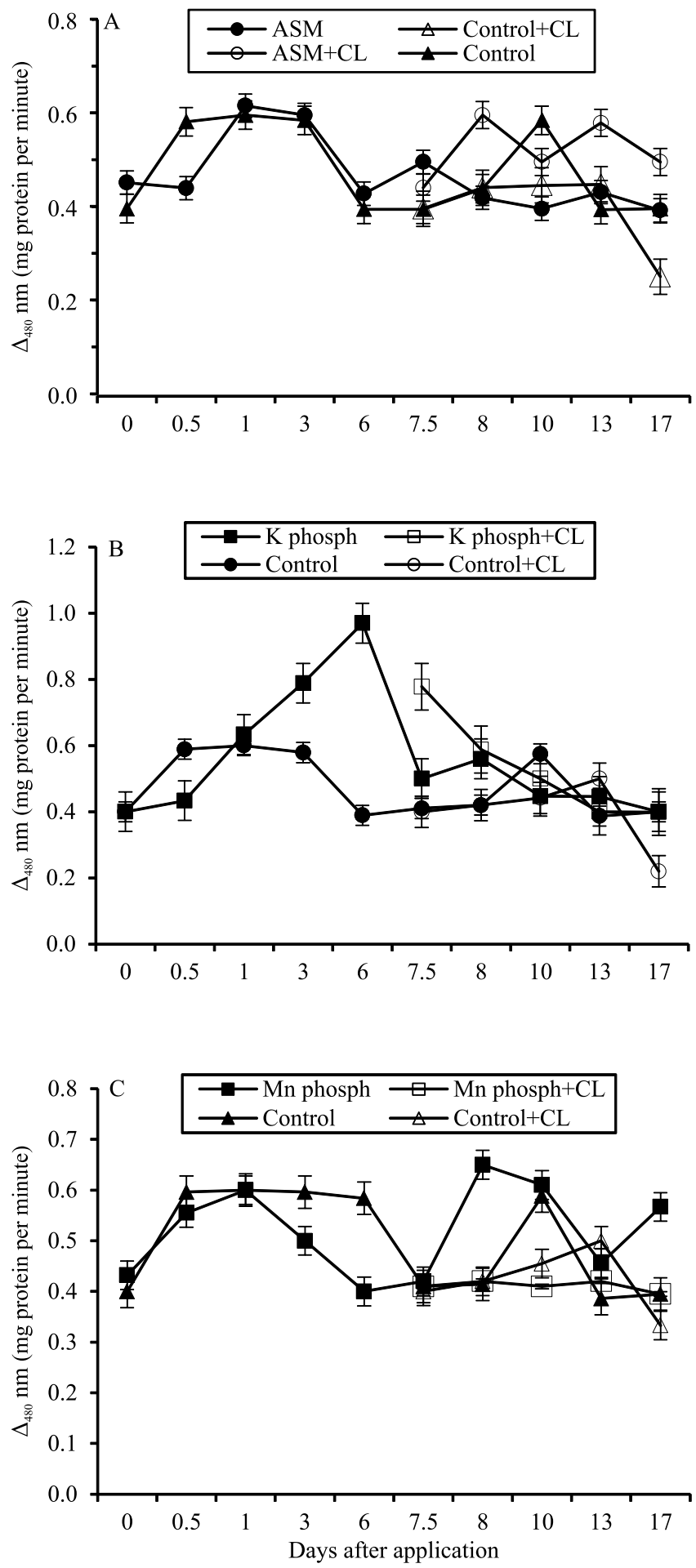

Figure 4. Activity of polyphenol oxidase in 'BRS Majestoso' common bean (Phaseolus vulgaris) leaves after treatment with: A, acibenzolar-S-methyl (ASM); B, potassium phosphite ( $\mathrm{K}$ phosph); and $\mathrm{C}$, manganese phosphite (Mn phosph), compared with the control. The inoculation with Colletotrichum lindemuthianum (CL) occurred seven days after spraying. Bars indicate standard deviation. 
L.) leaves. Regarding lignin content, no differences were verified between the treatments, in alignment with the results of Daniel \& Guest (2006). These authors inoculated Arabidopsis thaliana (L.) Heynh. with Phytophthora palmivora in a medium containing $\mathrm{K}$ phosphite and reported phenolic accumulation at the site of infection 6 hours after inoculation and that these compounds were concentrated around the infected cells after 48 hours.

Table 1. Content of total soluble phenols (TSP) in leaves of 'BRS Majestoso' common bean (Phaseolus vulgaris) plants, after 10,13, and 17 days application of treatment with acibenzolar-S-methyl (ASM), K phosphite, and Mn phosphite $^{(1)}$.

\begin{tabular}{lccc}
\hline \multirow{2}{*}{ Treatment $^{(2)}$} & \multicolumn{3}{c}{ TSP $\left(\mu \mathrm{g} \mathrm{mg}^{-1}\right.$ per dry weight of catechol $)$} \\
\cline { 2 - 4 } & 10 days & 13 days & 17 days \\
\hline ASM & $1.49 \mathrm{~b}$ & $1.57 \mathrm{a}$ & $1.56 \mathrm{~A}$ \\
ASM+CL & $1.77 \mathrm{a}$ & $1.72 \mathrm{a}$ & $1.65 \mathrm{~A}$ \\
K phosphite & $1.65 \mathrm{a}$ & $1.63 \mathrm{a}$ & $1.60 \mathrm{~A}$ \\
K phosphite+CL & $1.54 \mathrm{~b}$ & $1.68 \mathrm{a}$ & $1.63 \mathrm{~A}$ \\
Mn phosphite & $1.77 \mathrm{a}$ & $1.63 \mathrm{a}$ & $1.52 \mathrm{~A}$ \\
Mn phosphite+CL & $1.87 \mathrm{a}$ & $1.73 \mathrm{a}$ & $1.56 \mathrm{~A}$ \\
Control & $1.32 \mathrm{~b}$ & $1.53 \mathrm{a}$ & $1.54 \mathrm{~A}$ \\
Control+CL & $1.42 \mathrm{~b}$ & $1.43 \mathrm{a}$ & $1.50 \mathrm{~A}$ \\
\hline CV $(\%)$ & 11.50 & 12.29 & 10.10 \\
\hline
\end{tabular}

(1) Means followed by equal letters, in the columns, do not differ by Scott-Knott's test, at $5 \%$ probability. ${ }^{(2)}$ Inoculation of Colletotrichum lindemuthianum (CL) occurred seven days after spraying with treatments. CV, coefficient of variation.

Table 2. Content of soluble lignin in leaves of 'BRS Majestoso' common bean (Phaseolus vulgaris) plants, after 10,13 , and 17 days application of treatment with acibenzolarS-methyl (ASM), K phosphite, and Mn phosphite ${ }^{(1)}$.

\begin{tabular}{lccc}
\hline Treatment & $(2)$ & \multicolumn{3}{c}{ Soluble lignin $\left(\mu \mathrm{g} \mathrm{mg}^{-1}\right.$ per dry weight of catechol $)$} \\
\cline { 2 - 4 } & 10 days & 13 days & 17 days \\
\hline ASM & $23.52 \mathrm{a}$ & $26.45 \mathrm{a}$ & $25.34 \mathrm{a}$ \\
ASM+CL & $28.38 \mathrm{a}$ & $26.81 \mathrm{a}$ & $26.89 \mathrm{a}$ \\
K phosphite & $28.27 \mathrm{a}$ & $23.85 \mathrm{a}$ & $25.77 \mathrm{a}$ \\
K phosphite+CL & $28.22 \mathrm{a}$ & $26.49 \mathrm{a}$ & $25.97 \mathrm{a}$ \\
Mn phosphite & $27.49 \mathrm{a}$ & $28.44 \mathrm{a}$ & $24.49 \mathrm{a}$ \\
Mn phosphite+CL & $27.23 \mathrm{a}$ & $25.86 \mathrm{a}$ & $25.35 \mathrm{a}$ \\
Control & $26.17 \mathrm{a}$ & $26.90 \mathrm{a}$ & $23.28 \mathrm{a}$ \\
Control+CL & $22.80 \mathrm{a}$ & $23.44 \mathrm{a}$ & $22.49 \mathrm{a}$ \\
\hline CV $(\%)$ & 11.00 & 13.70 & 9.90 \\
\hline
\end{tabular}

(1)Means followed by equal letters, in the columns, do not differ by Scott-Knott's test, at $5 \%$ probability. ${ }^{(2)}$ Inoculation of Colletotrichum lindemuthianum (CL) occurred seven days after spraying with treatments. CV, coefficient of variation.

\section{Conclusions}

1. Phosphites can control and reduce anthracnose in common bean (Phaseolus vulgaris) and can be used as an alternative control method.

2. Phosphite applications on common bean leaves increase the activity of peroxidases and polyphenol oxidases, as well as total soluble proteins, and are effective in the control of anthracnose.

\section{Acknowledgments}

To Ministério da Ciência e Tecnologia de Moçambique, for financial support to the first author.

\section{References}

ARAÚJO, L.; VALDEBENITO-SANHUEZA, R.M.; STADNIK, M.J. Avaliação de formulações de fosfito de potássio sobre Colletotrichum gloeosporioides in vitro e no controle pósinfeccional da mancha foliar de Glomerella em macieira. Tropical Plant Pathology, v.35, p.54-59, 2010. DOI: 10.1590/ S1982-56762010000100010.

BONALDO, M.B.; PASCHOLATI, S.F.; ROMEIRO, R.S. Indução de resistência: noções básicas e perspectivas. In: CAVALCANTI, L.S.; DI PIERO, R.M.; PASCHOLATI, I.S.F.; RESENDE, M.L.V. de; ROMEIRO, R. da S. (Ed.). Indução de resistência em plantas a patógenos e insetos. Piracicaba: Fealq, 2005. p.11-28.

BORSATO, L.C.; DI PIERO, R.M.; STADNIK, M.J. Mecanismos de defesa eliciados por ulvana contra Uromyces appendiculatus em três cultivares de feijoeiro. Tropical Plant Pathology, v.35, p.318-322, 2010. DOI: 10.1590/S1982-56762010000500008.

BRADFORD, M.M. A rapid and sensitive method for the quantitation of microgram quantities of protein utilizing the principle of protein-dye binding. Analytical Biochemistry, v.72, p.248-254, 1976.

BUFFARA, C.R.S.; ANGELOTTI, F.; TESSMANN, D.J.; SOUZA, C.D. de; VIDA, J.B. Atividade de fosfito de potássio na pré e pós-infecção de Phakopsora euvitis em folhas de videira. Semina: Ciências Agrárias, v.34, p.3333-3340, 2013. Suplemento 1. DOI: $10.5433 / 1679-0359.2013 v 34 n 6$ Supllp3333.

CARBONELL, S.A.M.; CHIORATO, A.F.; CARVALHO, C.R.L.; RAMOS JUNIOR, E.U.; ITO, M.A.; BORGES, W.L.B.; TICELLI, M.; SANTOS, N.C.B. dos; BOLLER GALLO, P. IAC Formoso: new carioca common bean cultivar. Crop Breeding and Applied Biotechnology, v.10, p.374-376, 2010. DOI: 10.1590/ S1984-70332010000400014.

CHIORATO, A.F.; CARBONELL, S.A.M; VENCOVSKY, R.; FONSECA JÚNIOR, N. da S.; PINHEIRO, J.B. Genetic gain in the breeding program of common beans at IAC from 1989 to 2007.

Crop Breeding and Applied Biotechnology, v.10, p.329-336, 2010. DOI: 10.1590/S1984-70332010000400007. 
DALIO, R.J.D.; FLEISCHMANN, F.; HUMEZ, M.; OSSWALD, W. Phosphite protects Fagus sylvatica seedlings towards Phytophthora plurivora via local toxicity, priming and facilitation of pathogen recognition. PLoS One, v.9, e87860, 2014. DOI: 10.1371/journal.pone.0087860.

DANIEL, R.; GUEST, D. Defence responses induced by potassium phosphonate in Phytophthora palmivora-challenged Arabidopsis thaliana. Physiological and Molecular Plant Pathology, v.67, p.194-201, 2006. DOI: 10.1016/j.pmpp.2006.01.003.

DERCKS, W.; CREASY, L.L. Influence of fosetyl-Al on phytoalexin accumulation in the Plasmopara viticola-grapevine interaction. Physiological and Molecular Plant Pathology, v.34, p.203-213, 1989. DOI: 10.1016/0885-5765(89)90044-1.

DOSTER, M.A.; BOSTOCK, R.M. Quantification of lignin formation in almond bark in response to wounding and infection by Phytophthora species. Phytopathology, v.78, p.473-477, 1988.

FELIPINI, R.B.; DI PIERO, R.M. PR-protein activities in table beet against Cercospora beticola after spraying chitosan or acibenzolar-S-methyl. Tropical Plant Pathology, v.38, p.534538, 2013. DOI: 10.1590/S1982-56762013000600009.

FUZITANI, E.J.; SANTOS, A.F. dos; MORAES, W. da S.; DAMATTO JUNIOR, E.R.; NOMURA, E.S. Eficiência de fosfitos no controle da podridão da base do estipe em mudas de pupunheira. Revista Brasileira de Fruticultura, v.35, p.10001006, 2013.

GARCIA, R.A.; JULIATTI, F.C.; BARBOSA, K.A.G.; CASSEMIRO, T.A. Atividade antifúngica de óleo e extratos vegetais sobre Sclerotinia sclerotiorum. Bioscience Journal, v.28, p.48-57, 2012.

GAUILLARD, F.; RICHARDFORGET, F.; NICOLAS, J. New ectrophotometric assay for polyphenol oxidase activity. Analytical Biochemistry, v.215, p.59-65, 1993.

GODOY, C.V.; CARNEIRO, S.M.T.P.G.; IAMAUTI, M.T.; DALLA PRIA, M.; AMORIM, L.; BERGER, R.D.; BERGAMIN FILHO, A. Diagrammatic scales for bean diseases: development and validation. Zeitschrift für Pflanzenkrankheiten und Pflanzenschutz, v.104, p.336-345, 1997.

GUEST, D.; GRANT, B. The complex action of phosphonates as antifungal agents. Biological Reviews, v.66, p.159-187, 1991.

LINS, S.R. de O.; OLIVEIRA, S.M.A. de; ALEXANDRE, E.R.; SANTOS, A.M.G. OLIVEIRA, T.A.S. de. Controle alternativo da podridão peduncular em manga. Summa Phytopathologica, v.373, p.121-126, 2011. DOI: 10.1590/S0100-54052011000300007.

LOON, L.C. van; STRIEN, E.A. van. The families of pathogenesisrelated proteins, their activities, and comparative analysis of PR-1 type proteins. Physiological and Molecular Plant Pathology, v.55, p.85-97, 1999.

NEGRI, G.; BIASI, L.A.; WORDELL FILHO, J.W.; MAY-DE MIO, L.L. Manejo da queima das flores e da podridão-parda do pessegueiro cultivado em sistema orgânico. Revista Brasileira de Fruticultura, v. especial, E.415-423, 2011.

RAVA, C.A.; SARTORATO, A. Antracnose. In: SARTORATO, A.; RAVA, C.A. (Ed.). Principais doenças do feijoeiro comum e seu controle. Brasília: EMBRAPA-SPI, 1994. p.17-39. (EMBRAPA-CNPAF. Documentos, 50).

REUVENI, M. Post-infection applications of $\mathrm{K}_{3} \mathrm{PO}_{3}$, phosphorous acid and dimethomorph inhibit development of downy mildew caused by Plasmopara viticola on grapes. Journal of Small Fruit and Viticulture, v.5, p.27-38, 1997. DOI: 10.1300/J065v05n02_03.

RIBEIRO JÚNIOR, P.M.; RESENDE, M.L.V. de; PEREIRA, R.B.; CAVALCANTI, F.R.; AMARAL, D.R.; PÁDUA, M.A. de. Fosfito de potássio na indução de resistência a Verticillium dahliae Kleb., em mudas de cacaueiro (Theobroma cacao L.). Ciência e Agrotecnologia, v.30, p.629-636, 2006. DOI: 10.1590/ S1413-70542006000400006.

SHANER, G.; FINNEY, R.E. The effect of nitrogen fertilization on the expression of slow-mildewing resistance in Knox wheat. Phytopathology, v.67, p.1051-1056, 1977.

SILVA, M.S. e; CARVALHO, F.C.Q.; SILVA, J.R. da; LINS, S.R. de O.; OLIVEIRA, S.M.A. de. Uso de antagonistas e produtos alternativos no manejo pós-colheita de podridão mole em pimentão. Revista Ciência Agronômica, v.45, p.718-725, 2014. DOI: 10.1590/S1806-66902014000400009.

SILVA, O.C.; SANTOS, H.A.A.; DESCHAMPS, C.; DALLA PRIA, M.; MAY DE MIO, L.L. Fontes de fosfito e acibenzolarS-metílico associados a fungicidas para o controle de doenças foliares na cultura da soja. Tropical Plant Pathology, v.38, p.7277, 2013. DOI: 10.1590/S1982-56762013000100012.

SPANOS, G.A.; WROLSTAD, R.E. Influence of processing and storage on the phenolic composition of Thompson Seedless grape juice. Journal of Agricultural and Food Chemistry, v.38, p.1565-1571, 1990. DOI: 10.1021/jf00097a030.

TAVARES, G.M.; LARANJEIRA, D.; LUZ, E.D.M.N.; SILVA, T.R.; PIROVANI, C.P.; RESENDE, M.L.V. de; RIBEIRO JÚNIOR, P.M. Indução de resistência do mamoeiro à podridão radicular por indutores bióticos e abióticos. Pesquisa Agropecuária Brasileira, v.44, p.1416-1423, 2009. DOI: 10.1590/ S0100-204X2009001100007.

URBANEK, H.; KUZNIAK-GEBAROWSKA, E.; HERKA, H. Elicitation of defence responses in bean leaves by Botrytis cinerea polygalacturonase. Acta Physiologiae Plantarum, v.13, p.43-50, 1991. 